\title{
Heinrich Glück, Der Breit- und Langhausbau in Syrien
}

\section{John Shapley}

To cite this article: John Shapley (1920) Heinrich Glück, Der Breit- und Langhausbau in Syrien, The Art Bulletin, 3:3, 138-139, DOI: 10.1080/00043079.1920.11409696

To link to this article: http://dx.doi.org/10.1080/00043079.1920.11409696

曲 Published online: 22 Dec 2015.

Submit your article to this journal $₫$

Q View related articles $\widetilde{ }$ 
These various outstanding matters will no doubt be detrimental to the simple orderliness of a future, more adequate, tabulation. 'They will possibly make it asymmetrical, just as the old form of the table given at the beginning of this review has been made asymmetrical by the necessity of introducing Handuerk into the later form. But art, like life, is hard to reduce to mere symmetry, Hambidge to the contrary notwithstanding. We have long been thankful to Strzygowski for his efforts to introduce order into chaos and now we may be thankful for the additional clarification of method that Glück's book offers. The little book gives in limited space an amazing amount of food for thought.

\section{JoHN SHaPley.}

Heinrich Glück, Der Breit- und Langhausbau in Syrien, Heidelberg, Winter, 1916. 95 pp.; 49 figs.; 4 pls.; 4 to.

In America the great work of Professor Butler in paving the way by a series of expeditions for the study of the architectural riches of Early Christian Syria has never been adequately appreciated. An eye-opener for us is Glück's contribution, which deals particularly with the geographical problems connected with Syrian architecture. Resting almost wholly on the descriptions and illustrations of Butler (though the reports of others have been utilized as far as they are available for the purpose, and (Glück himself has visited Syria) he has been able to shed considerable light on the problems of Syrian architecture by taking into account the geographical, social, and material considerations involved.

Writing first of the Haurân, Glück points out the close geological and geographical connection of the region with Arabia and its marked isolation from the Mediterranean coast. He follows in the architecture of this region the various stages of the conflict between the longitudinal Hellenistic building and what he calls the lateral Arabic one. The inevitable influence that the lack of wood and the presence of hard rolcanic stone exerted upon the structure and the decoration of the buildings of the Haurân is traced in detail. The massive transverse arches and the flat stone roofs are well known peculiarities. But there are innumerable other matters that vary from building to building according to the interplay of tradition, ne- 
cessity, and convenience. The strength of Arabic culture in this part of Syria throughout the Hellenistic domination makes the rapid and easy spread of Islam more intelligible. But that this culture was strong enough to have created an architecture of its own has never been fully admitted, especially since it is now known what a powerful influence Hellenism exerted as far into the interior as Petra.

To the north in the various mountain districts east of the Orontes and sometimes projecting far into the desert was an older and much thicker stratum of Hellenistic culture. Even here Glück finds, however, some Arabic and many Mesopotamian elements. In view of our present ignorance it would seem to be a hard matter to distinguish one from the other. What is perfectly clear is that the architecture is mainly dependent upon local traditions and local building materials.

Along the western coast of Syria, however, there are no such local developments; everything is swept along by the stream of Mediterranean commerce and culture.

A welcome illustrative addition to the book is the tabulation of numerous ground plans so that they may be readily compared. The maps showing the geological nature of different regions are also useful. There is much of this kind of work to be done in countries not so remote as Syria. In fact it is sometimes amazing how little progress has been made in cultural geography, since the publications of Ritter and his contemporaries. If Glück succeeds in arousing interest in this neglected field of inves. tigation and if he encourages further participation in the unravelling of the problems of the Near East his work will have a value far greater than that of its immediate results.

John Shapley. 